\title{
Multi-function Plant Defensin, Antimicrobial and Heavy Metal Adsorbent Peptide
}

\author{
Neda Mirakhorli ${ }^{1,}$, Zahra Norolah ${ }^{1}$, Samira Foruzandeh ${ }^{1}$, Fateme Shafizade ${ }^{1}$, Farzaneh Nikookhah ${ }^{2}$, \\ Behnaz Saffar ${ }^{3}$, Omid Ansari ${ }^{4}$ \\ ${ }^{1}$ Department of Plant Breeding and Biotechnology, Shahrekord University, Shahrekord, Iran \\ ${ }^{2}$ Department of Fisheries and Environmental Science, Shahrekord University, Shahrekord, Iran \\ ${ }^{3}$ Department of Genetic, Shahrekord University, Shahrekord, Iran \\ ${ }^{4}$ Ecofibre Industries Operations and Ananda Hemp, Brisbane, Australia \\ * Corresponding author: Neda Mirakhorli, Department of Plant Breeding and Biotechnology, Shahrekord University, Shahrekord, Iran. E-mail: \\ mirakhorli-n@agr.sku.ac.ir
}

\begin{abstract}
Background: Defensin peptide isolated from plants are often heterogeneous in length, sequence and structure, but they are mostly small, cationic and amphipathic. Plant defensins exhibit broad-spectrum antibacterial and antifungal activities against Gram-positive and Gram-negative bacteria, fungi and etc. Plant defensins also play an important role in innate immunity, such as heavy metal and some abiotic stresses tolerance.

Objectives: In this paper, in vitro broad-spectrum activities, antimicrobial and heavy metal absorption, of a recombinant plant defensin were studied.

Material and Methods: SDmod gene, a modified plant defensin gene, was cloned in pBISN1-IN (EU886197) plasmid, recombinant protein was produced by transient expression via Agroinfiltration method in common bean. The recombinant protein was tested for antibacterial activity against Gram-negative, Gram-positive bacteria and Fusarium sp. the effects of different treatments on heavy metal zinc absorption by this peptide were tested.

Results: We confirmed the antibacterial activities of this peptide against Gram-negative (Escherichia coli and Pseudomonas aeruginosa) and Gram-positive (Staphylococcus aureus and Bacillus cereus) bacteria, and antifungal activities of this peptide against Fusarium spp. (Fusarium oxysporum and Fusarium solani). High metal absorption coefficient for this peptide was also observed.

Results: Out of six actinobacterial isolates, VITVAMB 1 possessed the most efficient RO-16 decolorization property. It decolorized $85.6 \%$ of RO-16 (250 $\left.\mathrm{mg} \mathrm{L}^{-1}\right)$ within $24 \mathrm{hrs}$. Isolate VITVAMB 1 was identified to be Nocardiopsis sp. Maximum dye decolorization occurred at $\mathrm{pH} 8$, temperature $35^{\circ} \mathrm{C}, 3 \%$ salt concentration and a dye concentration of $50 \mathrm{mg} \mathrm{L}^{-1}$.

Conclusions: Results suggesting that modified defensin peptide facilitates a broader range of defense activities. dedefensins are an important part of the innate immune system in eukaryotes. These molecules have multidimensional properties that making them promising agents for therapeutic drugs.

Keywords: Antibacterial Effect; Heavy Metal Adsorption; Plant Defensin; Therapeutic Potential
\end{abstract}

\section{Background}

Plant defensins are small cationic peptides consisting of low number (45-54) of amino acid residues with conserved cysteines that can form four disulfide bridges (1). Plant defensins comprised of tertiary structure including a single $\alpha$-helix and triple-stranded antiparallel $\beta$ - sheet. The complex results in formation of a compact shape by its four disulfide bridges $(2,3)$. Plant defensins were first studied in wheat and barley (4). Since 1990s, researchers have been studying antibacterial properties of cationic plant cysteine-rich antimicrobial peptides (AMP), the role of defensins in plant immune system is well reported $(3,5)$. Variations in the amino acids sequences result in small conformational changes in the tertiary structure of a protein. Ultimately these possible variations contribute to biological activities in functional properties of these proteins. One single amino acid substitution can lead to change in the functional activities including antifungal, 
antibacterial, enzyme inhibitory behaviors. These possible changes have been reported to play a role in heavy metal absorption and abiotic stress-tolerance (6).

\section{Objectives}

The antimicrobial activities of plant defensins were mainly observed as they apply to fungi $(7,8)$ and less so to bacteria (9). Plant defensins can be highly expressed or upregulated when plants are exposed to various abiotic stresses such as drought, salt, cold and heavy metals (6). In this paper the in vitro broad-spectrum activities of recombinant defensin (SDmod) protein have been investigated. The SDmod gene is a modified plant defensin that facilitates a broader range of defensin activities, based on the $s d 2$ gene sequence from Sunflower (3). In this study the recombinant SDmod protein was produced by transient expression in common bean.

\section{Materials and Methods}

\subsection{Genes, Plasmid and Microorganisms}

The SDmod gene, a modified defensin gene (3), was cloned with the marker gene LicBM2 in pBISN1-IN (EU886197) plasmid (Fig. 1). In this experiment, LicBM2, isolated from the bacterium Clostridium thermocellum, encodes the thermostable lichenase enzyme and was used as a safe reporter gene. Bacterial $\beta$-1,3-1,4-glucanases (EC 3.2.1.73; lichenase) specifically cleave the $\beta$-1,4-glycosidic linkage adjacent to 3-O-substituted glucopyranose residues (10). DNS method was used to measure enzymatic activity and reducing sugars (11) to define the recombinant protein in transgenic plants. Two constructs of pBISN1-IN plasmid (one with the SDmod gene and one without) was used to eliminate the effects of the marker gene.

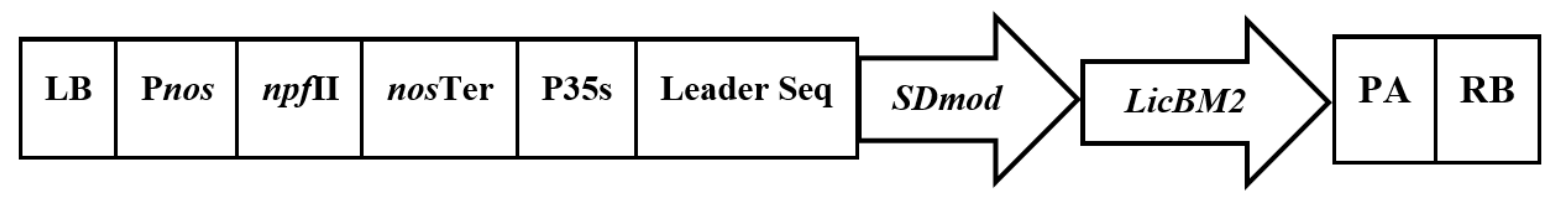

Figure 1. Gene construct of T-DNA region of pBISN1-IN plasmid.

The bacteria Escherichia coli DH5 $\alpha$ and Agrobacterium tumefaciens LBA4404 were used for gene cloning and plant transformation respectively.

\subsection{Transient Expression by Agroinfiltration Method} The vectors were transferred to A. tumefaciens LBA4404 using the electroporation method (12). $1 \mathrm{~mL}$ of overnight culture of transformed Agrobacterium containing $50 \mathrm{mg} . \mathrm{L}^{-1}$ kanamycin, $100 \mathrm{mg} . \mathrm{L}^{-1}$ rifampicin, was added to $100 \mathrm{~mL}$ Infiltration medium containing $100 \mu \mathrm{M}$ acetosyringone, $50 \mathrm{mg} . \mathrm{L}^{-1}$ kanamycin and 100 mg. $\mathrm{L}^{-1}$ rifampicin, and was incubated in $28{ }^{\circ} \mathrm{C}$ with continuous shaking $(190 \mathrm{rpm})$ for 6 hours. The culture centrifuged (5min, $40000 \mathrm{rpm}$ ) and the pellet resuspended in infiltration medium of $200 \mu \mathrm{M}$ acetosyringone (adjusted to $\mathrm{OD}_{600}=0.4$ ). Each leaf was injected using syringe infiltration with two types of infiltration medium (transformed bacteria and nontransformed bacteria) (Fig. 2).

\subsection{Protein Extraction}

Three days after infiltration, the injected leaves were harvested and grinded in a pestle and mortar with liquid nitrogen. Extraction buffer $(250 \mathrm{~mL}$ of $150 \mathrm{mMTrisHCl}$ $\mathrm{pH}=8$ ) was added to each sample, homogenized and centrifuged at $12000 \mathrm{rpm}$ for $20 \mathrm{~min}$ at $4^{\circ} \mathrm{C}$. The supernatant liquid containing the total proteins fraction (protein extract) was transferred to clean micro tubes.

\subsection{Selection of Recombinant Proteins}

The existence of recombinant protein (defensinelichenase) in the extracted plant proteins were definded by lichenase enzyme activity and reducing sugars measured by the DNS method (11). Modified Ellman's test was used to estimate the recombinant defensing quantities in plant protein solutions (13). This method can measure the number of cysteine and thiol groups in proteins $(14,15)$. In this study $1 \mathrm{M}$ of recombinant protein proved to contain $9 \mathrm{M}$ of cysteine.

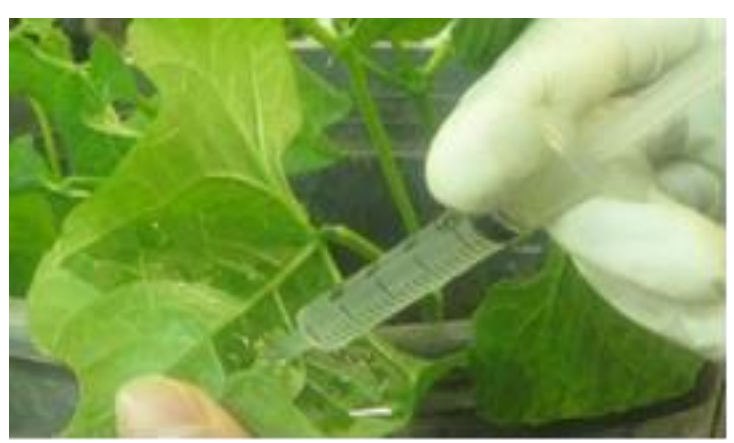

Figure 2. Infiltrating agrobacterium into been epidermal cells for transient expression.

\subsection{Antimicrobial Activity Assay}

Following the method of Bhalodia and et al (2011), potato dextrose agar (PDA) and Mueller Hinton Agar (MHA) were used to measure the antifungal and antibacterial susceptibility using the disk diffusion and agar-well diffusion methods (16). Two recombinant protein(with and without recombinant defensing protein) were produced by transforming two different contracts (LicBM2 and SDmod-LicBM2) using transient expression, to eliminate antimicrobial effect of lichenase enzyme and test the antimicrobial effects of recombinant defensin protein produced in this study.

The extracted proteins from the injected leaf by nontransgenic bacteria were used as control to eliminate 
antimicrobial effect of plant and bacteria proteins. Protein sample aliquot of $150 \mu \mathrm{L}$ was added to wells with Three recombinant protein defensin-lichenase concentrations $\left(5 \times 10^{-10}, 10 \times 10^{-10}\right.$ and $\left.20 \times 10^{-10} \mu \mathrm{M}\right)$ alongside with recombinant protein Lichenase, Kanamycin antibiotic and Nystatin as positive control and protein extraction from the injected leaf by nontransformed bacteria as negative control.

The recombinant proteins were tested for antibacterial activity against known pathogens, Gram-negative Escherichia coli and Pseudomonas aeruginosa bacteria and Gram-positive Staphylococcus aureus and Bacillus cereus bacteria. In addition, recombinant proteins were also tested for antifungal activity of Fusarium spp (Fusarium oxysporum and Fusarium solani).

The halo/ clear zone diameters in bacteria media was measured after 8,16 and $24 \mathrm{~h}$ and in fungal media after $12,24,48$ and $72 \mathrm{~h}$.

\subsection{Preparing Proteins to Measure Metal Absorption Amount}

In order to investigate the effect of different treatments on heavy metal zinc absorption, we tested different times $(5,30,60,90,120,150$, and $180 \mathrm{~min})(17)$, different amounts of active recombinant protein $(10 \times 10-9, \quad 30 \times 10-9, \quad 50 \times 10-9, \quad 70 \times 10-9, \quad 90 \times 10-9$, $130 \times 10-9,150 \times 10-9 \mu \mathrm{M})(14)$, different $\mathrm{pH}$ treatments of buffer phosphate solution $(4,4.5,5,5.5,6,6.5,7,7.5$, and 8$)$ and six temperature levels $(20,25,30,30,35,40$, and $50{ }^{\circ} \mathrm{C}$ ). Here the protein of non-transgenic plant was used as control.

For preparing recombinant protein samples, $3 \mathrm{~mL}$ of buffer phosphate solution $(137 \mathrm{mM} \mathrm{NaCl}, 2.7 \mathrm{mM}$ KCL, $4.3 \mathrm{mM} \mathrm{Na} 2 \mathrm{Hpo} 4$, and $1.47 \mathrm{mM} \mathrm{KH} 2$ po4) was incubated with active recombinant protein, 10 percent mercaptoethanol and $2 \mu \mathrm{l}$ of 0.1 molar zinc sulfate $\left(\mathrm{Zn}\left(\mathrm{So}_{4}\right)_{2} 7 \mathrm{H}_{2} \mathrm{O}\right)$ for $2: 30$ hours at $35^{\circ} \mathrm{C}$. Densities of the zinc $\left(\mathrm{Zn}^{+2}\right)$ in samples were recorded by the atomic absorption system.

\subsection{Statistical Analysis}

Triplicated data were analyzed using SAS software. Mean values were compared at $0.05 \mathrm{p}$ value.

\section{Results}

\subsection{Antibacterial Effects}

The aim of this study was to investigate the antibacterial properties of the modified defensin protein on the selected gram-positive and -negative pathogenic bacteria.

Defensin-lichenase recombinant protein showed a greater inhibition and larger clear zone on bacterial culture media than recombinant lichenase protein compared with the controls. The highest concentration $\left(20 \times 10^{-10} \mu \mathrm{M}^{)}\right.$of protein formed a significantly larger clear zone compared with the alternate concentrations (Fig. 3).
Analysis of diameter of clear zones at different time points indicated that the halo diagonals were distinctly expressed at higher rates at the first stage of growth $(8 \mathrm{~h})$ across all bacteria. Over time the antimicrobial activity of the recombinant protein was declined. After $24 \mathrm{~h}$, no antibacterial activity of recombinant proteins was recorded, except for $S$. aureus where the effect was still obvious. In vitro longevity of recombinant protein activities in $P$. aeruginosa and $B$. cereus was up to $16 \mathrm{~h} \mathrm{In}$ contrast, due to bacteriostatic effects of the protein, E. coli antibacterial activity was up to $8 \mathrm{~h}$. In $S$. aureus this effect was bactericidal and killed the organism (Fig. 3).

The inhibition zone's mean size for four bacteria showed that E. coli was the least susceptible of the organisms tested, while $S$. aureus was the most sensitive (Fig. 4). Across all tested bacteria, the inhibitory effects of protein proved to be the greatest at initial times of growth (up to $8 \mathrm{~h}$ ), but these effects declined over time and the bacteria continued to grow after $24 \mathrm{~h}$. The suggested concentrations of recombinant defensine protein in this study were bacteriostatic and not bactericidal.

\subsection{Antifungal Effects}

As for the investigation of the antifungal activity of recombinant protein we used the highest concentration of protein $\left(20 \times 10^{-10} \mu \mathrm{M}\right)$.

Analysis of halo diagonals of clear zone at different growth time points $(12,24,43$ and $72 \mathrm{~h})$ showed that the antimicrobial activity of recombinant protein was reduced over time (Fig. 5).

In this study, recombinant defensing-lichinase protein antifungal activity similar to Nystatin, while recombinant lichinase protein had an insignificant effect on fungal growth (Fig. 6). In vitro antifungal effect of recombinant protein against $f$. oxysporum and $f$. solani are showed.

\subsection{Heavy Metal Absorption Effect}

The highest zinc absorption rate (3.73 ppm) by defensin protein was observed at $\mathrm{pH}=6$ (Fig. 7a). In this study, we found that $\mathrm{pH}$ is a key factor in biological absorption of zinc by recombinant defensin protein. Accordingly, $\mathrm{pH}=6$ was selected as suitable $\mathrm{pH}$ for the metal absorption experiment and subsequent analysis. Optimal temperature for zinc absorption by recombinant defensin protein was determined to be 35 ${ }^{\circ} \mathrm{C}$, at which the zinc-absorption reading of $0.774 \mathrm{ppm}$ was observed (Fig. 7 b).

We assessed seven time regimes $(5,30,60,90,120,150$, and $180 \mathrm{~min}$ ) to select optimal absorption. The absorption of zinc was decreased to $0.938 \mathrm{ppm}$ after 150 minutes (Fig. 7c). Density of recombinant defensin protein on zinc absorption was studied. Proteins with different densities were added to solutions containing 2 $\mu \mathrm{M}$ zinc 0.1 molar. The highest absorption rate at the density of $70 \times 10^{-9} \mu \mathrm{M}$ of recombinant protein as 1.53 ppm was observed (Fig. 7 d). 

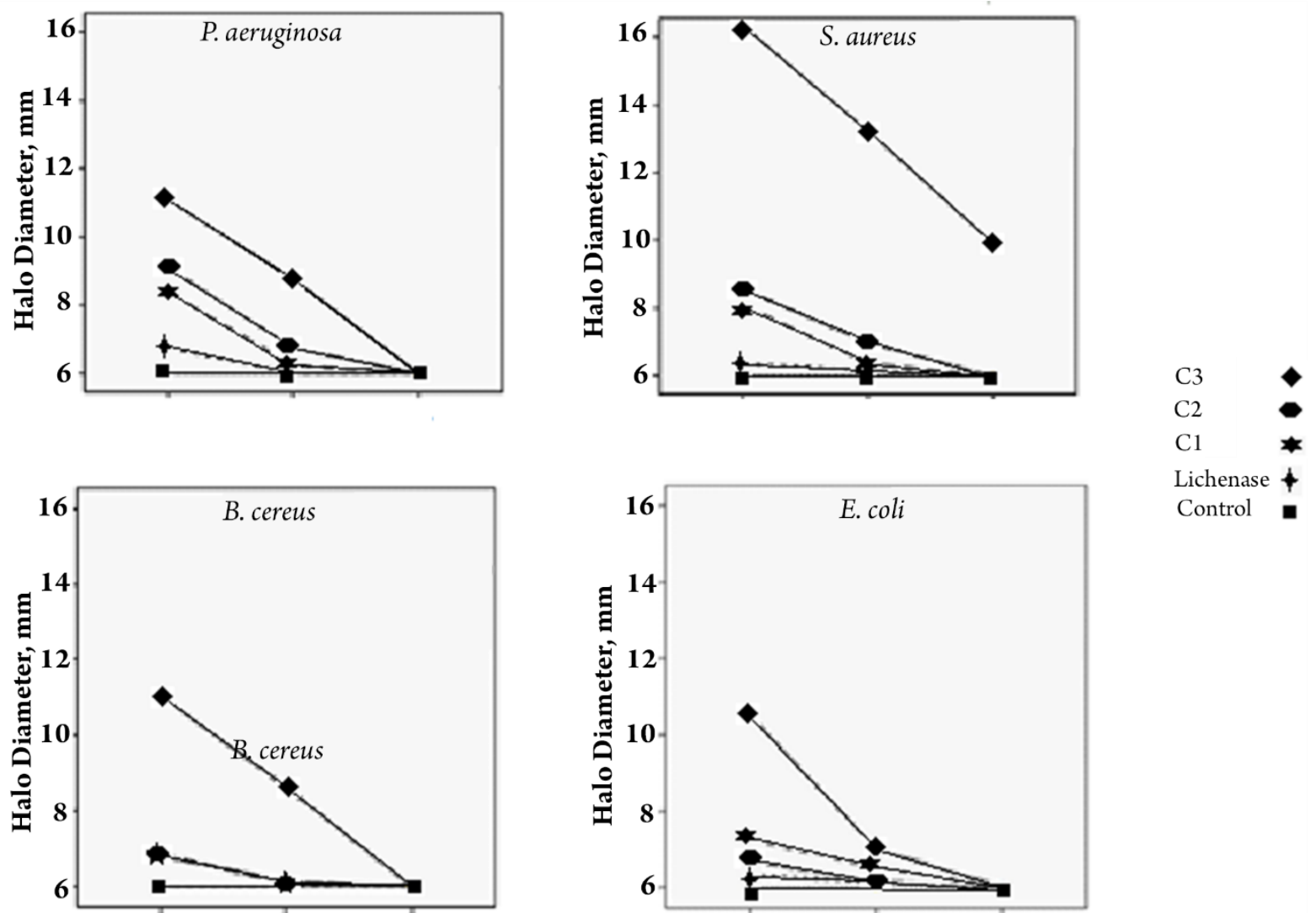

Figure 3. In Vitro antibacterial activity (halo/clear zone diameter) of three concentrations of recombinant defensin protein: $\mathrm{C}^{1}: 20 \times 10^{-10} \mu \mathrm{M}$. C2: $10 \times 10^{-}$ ${ }^{10} \mu \mathrm{M}$. C3: $5 \times 10^{-10} \mu \mathrm{M}$ compared to Lichenase enzyme and control(plant protein) in three times traetment, in gram positive and negative pathogenic bacteria; S. aureus, B. cereus, E. coli and P. aeruginosa.

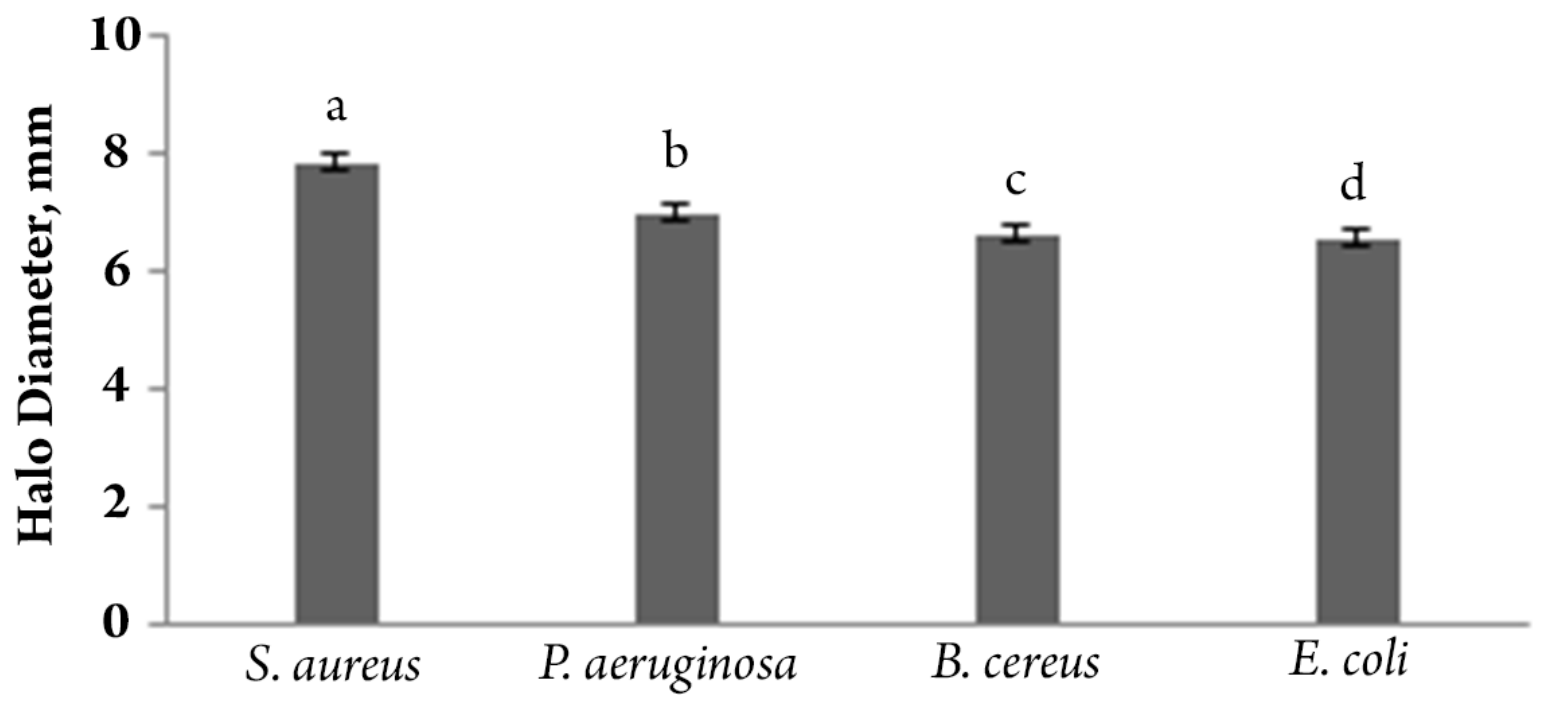

\section{Bacteria}

Figure 4. Comparison of antibacterial activity (inhibition halo diameter) of recombinant protein defensin produced by transient expression of SDmod gene in baen plant, against gram positive and negative pathogenic bacteria; S. aureus, B. cereus, E.coli and P. aeruginosa. (Treatments with at laest one letter are not significantly different in 5\% LSD test.) 

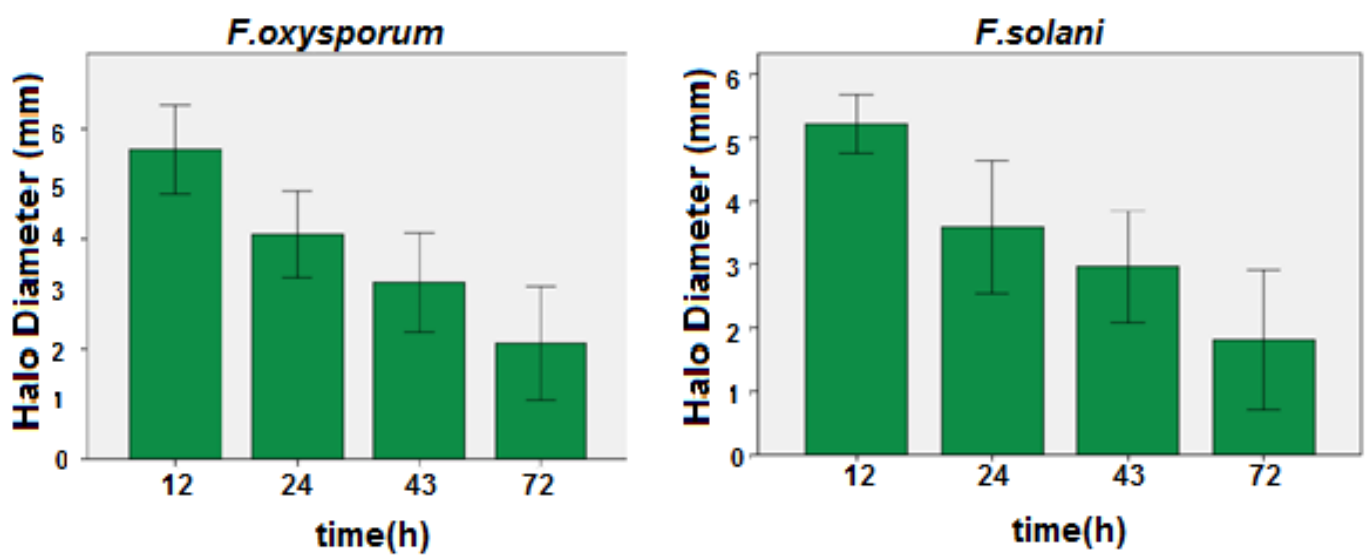

Figure 5. In vitro antifungall activity (halo/clear zone diameter) of recombinant protein (defensing-lichinase) produced by transient expression in four different times $(12,24,42$ and $72 \mathrm{~h}$ ) against F. oxysporum and F. solani.
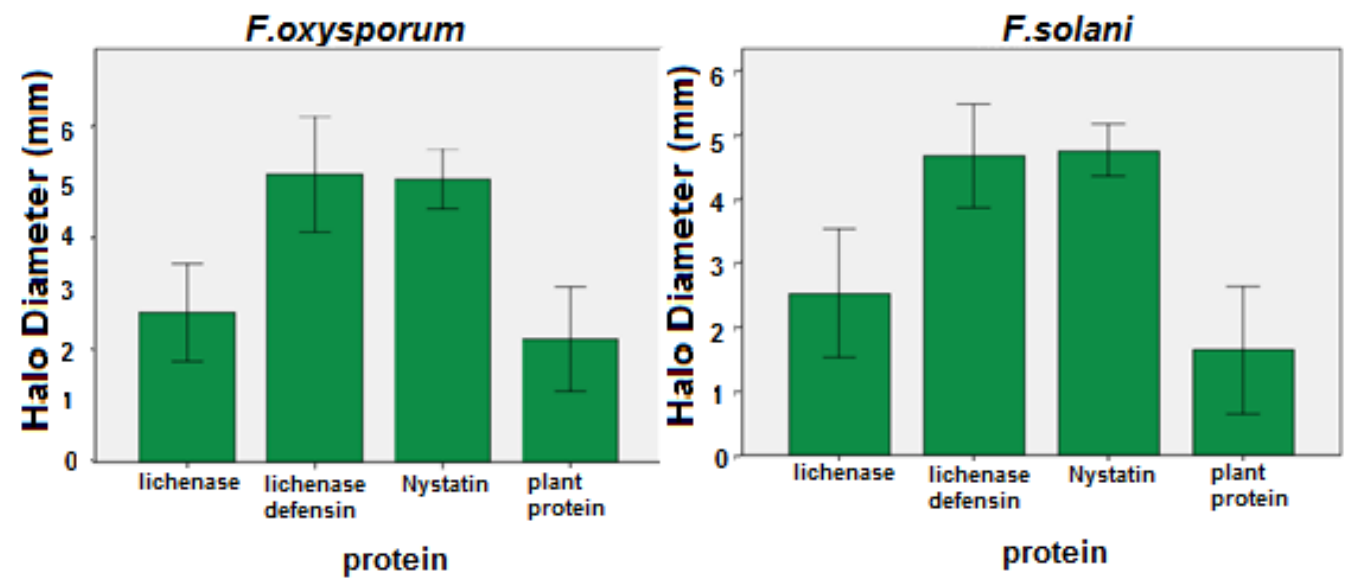

Figure 6. Antifungal activity of recombinant protein defensin-lichenase produced by transient expression compared to Lichenase, + controle (Nystatin) and -control (nontransgenic plant protein) against F. oxysporum and F. solani.
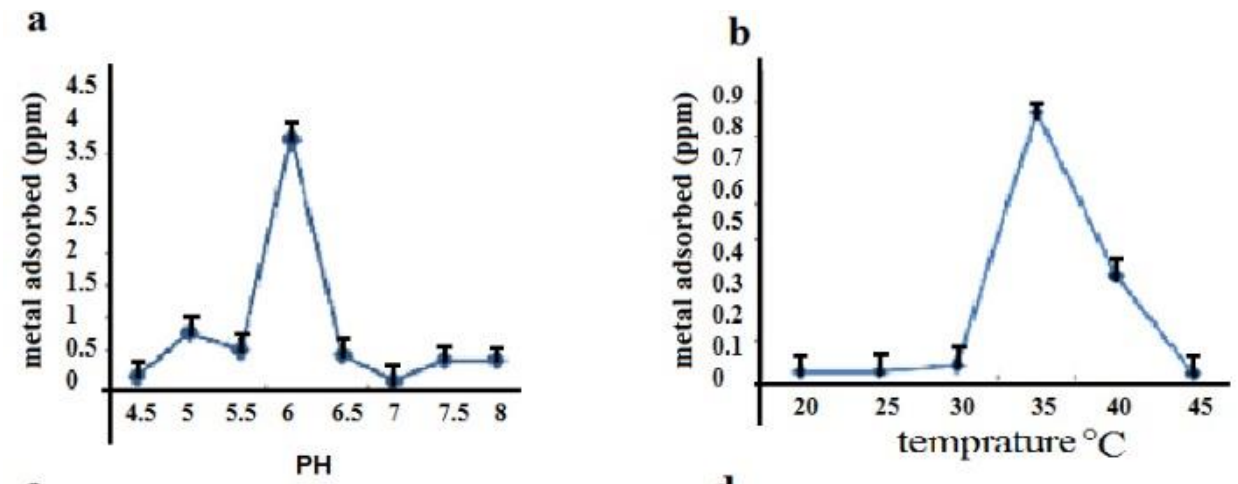

c

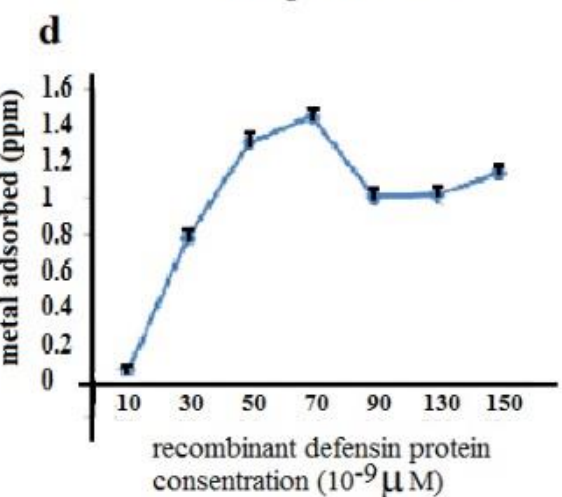

Figure 7. In vitro heavy metal (zinc) adsorption by recombinant defensin protein in different treatments of a: $\mathrm{PH}, \mathrm{b}:$ tempreture, c:time, d: protein concentrations 


\section{Discussion}

The studied recombinant defensin protein showed a broad spectrum of activities against fungi, gram positive and negative bacteria. One of the key function of defensins is its antimicrobial activity that plays a role in plant innate immunity $(16,18,19)$.With the exception of defensins with antibacterial $(10,20,21)$ and insecticide activities, most plant defensins have a powerful effect conferring systemic resistance against fungi (8).The cationic peptides, such as defensin, are attracted electrostatically to negatively charged molecules such as anionic phospholipids, lipopolysaccharides (LPS) and teichoic acid, which are located asymmetrically in the membrane structure and cause cell death $(16,22)$. Due to their high biocompatibility potential, moderate biodegradability, and low resistance developed on target microorganisms, defensins might prove to be a forthcoming novel class of antibiotics with application in several fields. Defensins can also be used to control fungal and bacterial infections in humans $(9,23)$. Defensis can be applied in controlling plant diseases as a new tool in crop protection programs $(5,24,25)$. Moreover, other applications of defensins have also been reported including: a replacement of or complement to antibiotics in animal nutrition; bio preservatives in food, cosmetics and biomaterials; and a substrate for antifouling $(2,6,8)$.

Natural defensins are generally known to have a narrow activity range aimed towards one or a few pathogens. To overcome this limitation, modified novel defensin peptides based on structure-activity studies have been developed $(3,26)$. For example, the SDmod gene has been modified to target a broader range of antimicrobial activities based on $s d 2$ gene sequence isolated from Sunflower (3). Since heavy metals are absorbed from pollutants without provoking any secondary pollution, biological techniques (ie application of defensins) appear to be one of the best solutions for absorbing heavy metals (27). Previous studies reported heavy metal cadmium absorption potential of this recombinant defensin protein (SDmod) experimentally and theoretically. Experimental results proved that the best absorption of cadmium by this recombinant defensin protein happens at the concentration of $150 \times 10^{-9} \mu \mathrm{M}$ of protein (14).

Environmental factors such as temperature, salt density, $\mathrm{pH}$, and biomass density influence the absorption level of heavy metal. Runping et al. (2006) introduced the effect of $\mathrm{pH}$ to be an important factor in absorption of lead and copper (28). Results of their study showed that capacity of absorption of heavy metal by yeast mass is increased when $\mathrm{pH}$ is increased from 2 to 6 . In $\mathrm{pH}$ lower than 2 , the least absorption was observed. Hence $\mathrm{pH}=5$ was selected as the optimal $\mathrm{pH}$. They also examined the effect of temperature as it influenced absorption of these metal ions by yeast. Temperatures varied between 20 to $50{ }^{\circ} \mathrm{C}$. As temperature increased, more copper- and less lead ions were absorbed by yeast. Therefore, this process appears to be endothermic for copper and exothermic for lead. Cadmium (14) and zinc absorption potential with recombinant defensin protein proves to be an endothermic process under temperatures up to $35^{\circ} \mathrm{C}$.

The amount of absorbed heavy metal ions by biomass is increased as time increases. The examination of the metal absorption in the yeast indicated that as the yeast's biomass increased, the absorption level of metal ions decreased (17).

\section{Conclusions}

As results indicate, as the mass of SDmod protein increases up to $70 \times 10^{-9} \mu \mathrm{M}$, the absorption level of zinc is increased. Due to this finding Mirouze et al. (2006) increased the tolerance towards zinc in the transgenic plant through transmission of the defensin gene AhPDF1.1 in A. thaliana (29). A study by Valls et al. (2000) proved that peptides bound to metals and metallothioneins cause more tolerance and aggregation of cadmium in E. coli cells (30). Another study by Nemeth et al. (2004) on hemostasis showed that defensins prevent heavy metal cations trafficking and, thus, increase zinc's tolerance. Environmental pollution by heavy metals and biological methods of absorption may justify the production and utilization of transgenic plants. Phytoremediation is defined as absorption of, or, possibly, recovery of heavy metals and other organic and inorganic materials from soil and water by virtue of engineered green plants. Identification of cysteine-rich proteins and production of metal-absorbent transgenic plants are apparent subjects to be followed up by environmental scientists. SDmod defensin is a cysteinerich protein that has been used as a model for the development of heavy metal removal systems in order to eliminate environmental pollutions.

\section{Acknowledgments}

This work was supported financially by Shahrekord University of Iran.

\section{References}

1. Carvalho Ade O, Gomes VM. Plant defensins-prospects for the biological functions and biotechnological properties. Peptides. 2009;30(5):1007-1020. doi: 10.1016/j.peptides.2009.01.018 pmid: 19428780

2. Gadd GM, de Rome L. Biosorption of copper by fungal melanin. Appl Microbiol Biotechnol. 1988;29(6):610617. doi: 10.1007/bf00260993

3. Sotchenkov DV, Goldenkova IV, Mirakholi N, Volkova LV. [Modification of the sunflower defensin SD2 gene sequence and its expression in bacterial and yeast cells]. Genetika. 2005;41(11):1453-1461. doi: 10.1007/s11177-005-0219-1 pmid: 16358712 
4. Colilla FJ, Rocher A, Mendez E. gamma-Purothionins: amino acid sequence of two polypeptides of a new family of thionins from wheat endosperm. FEBS Lett. 1990;270(1-2):191-194. doi: 10.1016/00145793(90)81265-p pmid: 2226781

5. Montesinos E. Antimicrobial peptides and plant disease control. FEMS Microbiol Lett. 2007;270(1):1-11. doi: 10.1111/j.1574-6968.2007.00683.x pmid: 17371298

6. Cleveland J, Montville TJ, Nes IF, Chikindas ML. Bacteriocins: safe, natural antimicrobials for food preservation. Int J Food Microbiol. 2001;71(1):1-20. doi: $\quad 10.1016 / \mathrm{s} 0168-1605(01) 00560-8$ pmid: 11764886

7. Broekaert WF, Cammue BPA, De Bolle MFC, Thevissen K, De Samblanx GW, Osborn RW, et al. Antimicrobial Peptides from Plants. Crit Rev Plant Sci. 2010;16(3):297-323.

doi: $10.1080 / 07352689709701952$

8. Kraszewska J, Beckett MC, James TC, Bond U. Comparative Analysis of the Antimicrobial Activities of Plant Defensin-Like and Ultrashort Peptides against Food-Spoiling Bacteria. Appl Environ Microbiol. 2016;82(14):4288-4298. doi: 10.1128/AEM.00558-16 pmid: 27208129

9. Hancock RE. Cationic peptides: effectors in innate immunity and novel antimicrobials. Lancet Infect Dis. 2001;1(3):156-164. doi: 10.1016/S14733099(01)00092-5 pmid: 11871492

10. Broekaert WF, Terras FR, Cammue BP, Osborn RW. Plant defensins: novel antimicrobial peptides as components of the host defense system. Plant Physiol. 1995;108(4):1353-1358. doi: 10.1104/pp.108.4.1353 pmid: 7659744

11. Miller GL. Use of Dinitrosalicylic Acid Reagent for Determination of Reducing Sugar. Anal Chem. 1959;31(3):426-428. doi: 10.1021/ac60147a030

12. Lee MW, Yang Y. Transient expression assay by agroinfiltration of leaves. Methods Mol Biol. 2006;323:225-229. doi: 10.1385/1-59745-003-0:225 pmid: 16739580

13. Ullah H, Khan MF, Jan SU, Hashmat F. Depletion of GSH in human blood plasma and cytosolic fraction during cadmium toxicity is temperature and $\mathrm{pH}$ dependent. Pak J Pharm Sci. 2016;29(1):89-95. pmid: 26826820

14. Mahnam K, Foruzandeh S, Mirakhorli N, Saffar B. Experimental and theoretical studies of cadmium ions absorption by a new reduced recombinant defensin. $J$ Biomol Struct Dyn. 2018;36(8):2004-2014. doi: 10.1080/07391102.2017.1340851 pmid: 28617190

15. Riener CK, Kada G, Gruber HJ. Quick measurement of protein sulfhydryls with Ellman's reagent and with 4,4'dithiodipyridine. Anal Bioanal Chem. 2002;373(45):266-276. doi: 10.1007/s00216-002-1347-2 pmid: 12110978

16. Barbosa Pelegrini P, Del Sarto RP, Silva ON, Franco OL, Grossi-de-Sa MF. Antibacterial peptides from plants: what they are and how they probably work. Biochem Res Int. 2011;2011:250349. doi: 10.1155/2011/250349 pmid: 21403856

17. Han R, Li H, Li Y, Zhang J, Xiao H, Shi J. Biosorption of copper and lead ions by waste beer yeast. J Hazard
Mater. 2006;137(3):1569-1576. doi: 10.1016/j.jhazmat.2006.04.045 pmid: 16737773

18. Nurnberger T, Brunner F, Kemmerling B, Piater L. Innate immunity in plants and animals: striking similarities and obvious differences. Immunol Rev. 2004;198:249-266. doi: 10.1111/j.01052896.2004.0119.x pmid: 15199967

19. Thomma BP, Cammue BP, Thevissen K. Plant defensins. Planta. 2002;216(2):193-202. doi: 10.1007/s00425-002-0902-6 pmid: 12447532

20. Osborn RW, De Samblanx GW, Thevissen K, Goderis I, Torrekens S, Van Leuven F, et al. Isolation and characterisation of plant defensins from seeds of Asteraceae, Fabaceae, Hippocastanaceae and Saxifragaceae. FEBS Lett. 1995;368(2):257-262. doi: 10.1016/0014-5793(95)00666-w pmid: 7628617

21. Segura A, Moreno M, Molina A, Garcia-Olmedo F. Novel defensin subfamily from spinach (Spinacia oleracea). FEBS Lett. 1998;435(2-3):159-162. doi: 10.1016/s0014-5793(98)01060-6 pmid: 9762899

22. Nizet V. Antimicrobial peptide resistance mechanisms of human bacterial pathogens. Curr Issues Mol Biol. 2006;8(1):11-26. pmid: 16450883

23. Zasloff M. Antimicrobial peptides of multicellular organisms. Nature. 2002;415(6870):389-395. doi: 10.1038/415389a pmid: 11807545

24. Coca M, Penas G, Gomez J, Campo S, Bortolotti C, Messeguer J, et al. Enhanced resistance to the rice blast fungus Magnaporthe grisea conferred by expression of a cecropin A gene in transgenic rice. Planta. 2006;223(3):392-406. doi: 10.1007/s00425-0050069-z pmid: 16240149

25. Marcos JF, Munoz A, Perez-Paya E, Misra S, LopezGarcia B. Identification and rational design of novel antimicrobial peptides for plant protection. Annu Rev Phytopathol. 2008;46:273-301. doi: 10.1146/annurev.phyto.121307.094843 pmid: 18439131

26. Badosa E, Moiset G, Montesinos L, Talleda M, Bardaji E, Feliu L, et al. Derivatives of the antimicrobial peptide BP100 for expression in plant systems. PLoS One. 2013;8(12):e85515.

doi: 10.1371/journal.pone.0085515 pmid: 24376887

27. García-Olmedo F, Molina A, Alamillo JM, RodríguezPalenzuéla P. Plant defense peptides. Biopolymers. 1998;47(6):479-491. doi: 10.1002/(sici)10970282(1998)47:6<479::aid-bip6>3.0.co;2-k

28. Runping J, Honglin Z, Yan S, Xingguo C, Zhide H. Human serum albumen enhanced resonance light scattering of dyes. Talanta. 2004;64(2):355-360. doi: 10.1016/j.talanta.2004.02.030 pmid: 18969611

29. Mirouze M, Sels J, Richard O, Czernic P, Loubet S, Jacquier A, et al. A putative novel role for plant defensins: a defensin from the zinc hyper-accumulating plant, Arabidopsis halleri, confers zinc tolerance. Plant J. 2006;47(3):329-342. doi: 10.1111/j.1365313X.2006.02788.x pmid: 16792695

30. Valls M, de Lorenzo V, Gonzalez-Duarte R, Atrian S. Engineering outer-membrane proteins in Pseudomonas putida for enhanced heavy-metal bioadsorption. J Inorg Biochem. 2000;79(1-4):219-223. doi: 10.1016/s01620134(99)00170-1 pmid: 10830869 